\title{
Nuclear Receptor Subfamily 1 Group D Member 1
}

National Cancer Institute

\section{Source}

National Cancer Institute. Nuclear Receptor Subfamily 1 Group D Member 1. NCI

Thesaurus. Code C101740.

Nuclear receptor subfamily 1 group D member 1 (614 aa, $\sim 67 \mathrm{kDa}$ ) is encoded by the human NR1D1 gene. This protein plays a role in transcriptional regulation of genes involved in metabolic processes and circadian rhythm. 